\title{
DIFFERENCES IN THE MODE OF SECRETION OF GOBLET CELLS IN THE UPPER RESPIRATORY TRACT OF VARIOUS VERTEBRATE CLASSES
}

\author{
I. TĚŠ́K \\ Department of Histology and Embryology, 1st Medical Faculty, Charles University, 12800 Prague
}

Received Fanuary 11, 1991

\begin{abstract}
Těšik, I.: Differences in the Mode of Secretion of Goblet Cells in the Upper Respiratoty Tract of Various Vertebrate Classes. Acta vet. Brno, 61, 1992: 11-15.

An investigation was made of the fate of secretory granules accumulated in the apical part of goblet cells in various vertebrate classes. In amphibians they hydrated steadily, increased in volume and gradually merged to form a uniform mucous mass which eventually emptied on to the surface of the mucosa.

In reptiles mucin granules hydrated only on the surface and left the cell without being entirely swollen. It was only extracellularly that they changed into definitive mucus in the course of continued hydration.

In birds most granules merged to form a homogenous mass but some of them left the cell in the state of only partial hydration.

In mammals, similarly to amphibians, secretory granules hydrated completely and most of them merged so that an almost homogenous mucous mass left the cell.
\end{abstract}

Goblet cell, secretion, upper respiratory tract

Goblet cells of the upper respiratory tract of various vertebrate classes appear to be more or less morphologically identical when observed under the light microscope. Electron microscopic studies, however, reveal considerable differences which are obviously due to a differing functional cycle of these cells in different vertebrate classes.

The ultrastructure of the goblet cell has been described by Taylor (1959), Bierring (1962), Freeman (1962), Kanamura (1975), Low (1961), Śimeček (1963), Trier (1963) a. o. Its shape is goblet-like on longitudal section and polygonal on transverse section. The nucleus is located in its narrowed basal part. The cytoplasm contains a considerable amount of free ribosomes, and mitochondria are scattered throughout the cell. Vigorously developed are endoplasmic re: $i$ isulum and the Golgi apparatus. These produce minute mucous droplets which aggregate to form larger granules (Florey 1960; Sherman and Muir 1960). According to Trier (1963) the matrix of the granules located deep in the cytoplasm is homogenous, whereas those occurring nearer the cell surface show a rather coarsely precipitated material.

\section{Materials and Methods}

Tissue specimens were obtained from 3 representatives each of 47 vertebrate species including 4 amphibian species, 21 reptile species, 7 bird species and 15 mammalian species, all of them adult males and females except crocodiles which were between only 58 and $80 \mathrm{~cm}$ in length.

In amphibians tissue specimens were taken from just behind the rima glottidis. In the remaining vertebrates tracheal samples were taken from approximately the middle of the trachea or just above the bifurcation of the bronchi. Human material was obtained by biopsy during bronchoscopy of clinically healthy subiects.

The tissue specimens were fixed on the one hand with $1 \% \mathrm{OsO}_{4}$ in $0.1 \mathrm{M}$ phosphate buffer, pH 7.4, for 3 hours at $0{ }^{\circ} \mathrm{C}$, on the other hand with $2.5 \%$ glutaraldehyde in the same buffer for 2 hours and postfixed with $1 \% \mathrm{OsO}$, for 1 hour at $0{ }^{\circ} \mathrm{C}$. They were embedded in Durcupan ACM and then sectioned with glass knives on a Porter-Blum microtome. Ultrathin sections were counterstained according to Reynolds (1963) and examined with a Tesla BS 500 electron microscope. 


\section{Results}

In amphibians and reptiles goblet cells were, for the most part, scattered irregularly among the other epithelial elements of the upper respiratory tract. Only in some snakes, croco liles and monitors more or less large clusters of goblet cells were observed. In monitors and birds such formations tended, in addition, to immerse below the level of the surrounding epithelium, thus giving rise to the development of endoepithelial glands. However, it was only in mammals that the tracheal glands represented exoepithelial formations quite distinctly.

The morphology of goblet cells was essentially the same whether they were scattered singly in the epithelium or centred in the glands. Their common feature was the presence of a vigorously developed granular endoplasmic reticulum. Differences, on the other hand, were observed in the fate of secretory granules accumulated in the apical part of the cell (see Plates XV. to XVIII.).

In amphibians and mammals the secretory granules hydrated steadily (Fig. 5 and 9 to 13), thus increasing in volume and gradually merging to form a uniform mucous mass which eventually emptied on to the surface of the mucosa (Fig. 5 and 11). In mammals it was found in addition that in some instances total discharge of the secretory product failed to occur; only the apically located homogenous mass of hydrated mucus left the cell, whereas the basally located mucin granules that had not merged remained temporarily in the cell. Added to these findings in mammals was the observation that occasionally it was not mucus alone that left the cell but, along with it, also a portion of the apical cytoplasm (Fig. 13).

In reptiles mucin granules hydrated only on the surface and left the cell without being completely swollen (Fig. 1 to 5), generally in clusters but in some instances also as single granules. The secretion of granules in clusters was typical particularly of testudinates in which occassionally even the separation of entire apical granule-filled parts of goblet cells was observed.

In birds most granules merged to form a homogenous mass but some of them left the cell in the state of only partial hydration (Fig. 3). Added to this in lamellirostral birds was the observation of a mosaic-like hydration of mucin granules, apparently a finding specific of these birds, which did not proceed from the surface to the inside but affected the granule concurrently in an islet-like pattern throughout its profile (Fig. 8).

\section{Discussion}

In all vertebrate classes goblet cells retain their basic morphological features as described by Bierring (1962), Freeman (1962), Kanamura (1975), Low (1961), Taylor (1959), Trier (1963), Těší (1978a, b, 1981, 1982, 1984a, b, 1986) a. o. In amphibians and reptiles these cells may not be invariably goblet-shaped; they may be also cubic or slightly flattened in shape. The structure of the lateral walls of goblet cells as well as the size and quantity of microvilli on their free surface depend apparently on the stage of their secretory cycle. Spoendlin (1959) has suggested that the microvilli of these cells may have a resorption function. According to him goblet cells have therefore a structural disposition for both resorption and secretion and can either produce or resorb mucus. From our study it appears, similarly to the observations reported by Trier (1963), that mucous granules arise by aggregation of minute mucin droplets which are homogenous at first, but if they later move to the apical part of the cell, their 
surface zones contain a rather coarsely precipitated material. Concurrently with their shift towards the apical part of the cell they obviously inbibe fluid, which is responsible for the different appearance of the granules within one and the same cell. By continued hydration the granules gain in volume, thus coming in close contact with one another, and push the cytoplasm towards the periphery of the cell. In amphibians, similarly to the observations made in mammals by Florey (1960) and Sherman and Muir (1960), the surface membranes of mucus granules that are in contact with one another become discontinuous. In consequence, the adjacent granules merge to form increasingly larger, totally hydrated formations. The mass of the mucous secretion thus arisen then empties on to the surface of the mucosa.

Somewhat different were our findings in reptiles where as a rule total intracellular hydration and mutual merging of mucin granules did not take place and we observed only their partial superficial swelling. In this state the mucin granules then leave the apical part of the cell and it is only extracellularly that they hydrate completely and change into the definitive mucus.

In birds the secretory process of goblet cells showed a kind of synthesis of the forms of secretion found in reptiles and mammals. Most mucin granules in the apical parts of goblet cells in birds hydrated totally and merged to form a homogenous mucous mass, but there were also seen a few single, only partially swollen, granules that did not change into the definitive mucus until they reached the mucosal surface where they arrived together with the bulk of the mucous secretory product of the goblet cell.

In the cytoplasm of the emptied goblet cells, however, we never observed the occurrence of large electron-dense granules as were described by Rhoddin and Dalhamn (1956) and were taken for cytosomes by Schulz and De Poala (1958).

We did never record the process of changes of a ciliated cell into a goblet cell which was described by Osada (1963) and the possibility of which was admitted by Fišer (1983).

Neither could we confirm the existence of two types of goblet cells in the tracheal epithelium of birds as was described in the domestic fowl by Purcell (1971).

\section{Rozdíly ve způsobu sekrece pohárkových buněk horních cest dýchacích rủzných tříd obratlovců}

V apikální části pohárkových buněk nahromaděná sekreční granula mohou mít odlišný osud.

U obojživelníků rovnoměrně hydratují, zvětšují se a postupně se slévají v jednotnou hlenovou masu, která se posléze vyleje na povrch sliznice.

U plazů mucinová zrna hydratují jen na povrchu a ne zcela zbobtnalá opouštějí buňku. Teprve extracelulárně se pokračující hydratací mění $\mathrm{v}$ definitivní hlen.

U ptákư se většina granul slévá v homogenni masu, ale některá opět opouštějí buňku ve stavu pouze částečného zvodnění.

$\mathrm{V}$ pohárkových buňkách savců, podobně jako u obojživelníků, sekreční granula hydratují totálně, většina se jich slévá a buňku opouští téměř homogenní hlenová masa. 


\section{Разница способа секреции чащевидных клеток верхних дыхательных пүтей разных классов позвоночных}

В верхушечной части чащевидных клеток скопленные секреторные гранули могут в дальнейшем развитии сүщественно отличаться.

У земноводных равномерно упомянутые клетки гидратируют, увеличиваясь и постепенно сливаясь в единую слизистүю массу, выливающуюся впоследствии на поверхность слизистой оболочки.

У пресмыкающихся мүцинозные зерна гидратируют лишь на поверхности и не полностью набухшие покидают клетку. Только внеклеточно под влиянием продолжающейся гидратации превращаются окончательно в слизь.

У птиц большинство гранул сливается в однородную массу, некоторые гранулы опять-таки покидают клетку в состоянии частичной гидратации.

В чашевидных клетках млекопитающих - аналогично земноводным - секреторные гранулы гидратируют полностью, большинство из них сливается и клетку покидает почти однородное слизистое вещество.

\section{References}

BEIRRING, F.: Electron microscopic observations on the mucus production in human and rat intestinal goblet cells. Acta Path. Microbiol. Scand., 54, 1962: 241-252

FISER, F.: Treatment methods in the discharge of bronchial secretion. Institute for Further Training of Middle Health Personnel, Brno, 1983 (In Czech)

FLOREY, H. W.: Electron microscopic observations on goblet cells of the rat colon. Quart. J. Exp. Physiol., 45, 1960: 329-336

FREEMAN, J. A.: Fine structure of the goblet mucous secretory process. Anat. Rec., 144, 1962: $341-358$

KANAMURA, S.: Ultrastructural localisation of Glucose-6-phosphatase activity in tracheal epithelium of the rat. J. Anat., 119, 1975: 499-504

LOW, F. N.: The extracellular portion of the human blood-air barrier and its relation to tissue space. Anat. Rec., 139, 1961 : 105-123

OSADA, M.: Electron microscopical observations on the human tracheal epithelium with special references to the ciliated cells. Arch. Histol. Jap., 24, 1963: 91-111

PURCELL, D. A.: The ultrastructure of tracheal epithelium in the fowl. Res. Vet. Sci., 12, 1971: $327-329$

REYNOLDS, E. S.: The use of lead citrate at high $\mathrm{pH}$ as an electron opaque stain in electron microscopy. J. Cell. Biol., 17, 1963: 208-212

RHODIN, J. A. G. - DALHAMN, T.: Electron microscopy of the tracheal ciliated mucosa in rat. Z. Zellforsch., 44, 1956: 345-412

SCHULZ, H. - DEPOALA, D.: Delta Cytomembranen und lamelläre Cytosomen. Z. Zellforsch., 49, 1958: 125-141

SHERMAN, D. J.-MUIR, A. R.: Observations on the secretory cycle of goblet cells. Quart. J. Exp. Physiol., 45, 1960: 337-342

SPOENDLIN, H.: Elektronmikroskopische Untersuchungen am respiratorischen Epitel der oberen Luftwege. Pract. Oto. Rhino. Laryng., 21, 1959: 484-498

ŠIMECEK, C.: Cytologická vyšetření v pneumologii. SZN, Praha, 1963.

TAYLOR, J. J.: Observation on the ultrastructure of the goblet cell of the rat duodenum. Anat. Rec., 133, 1959: 434-422

TĚSfK, I.: Ultrastructure of upper respiratory tract epithelium of certain species of amphibians. Proc. XIXth Morphol. Congr. Praha, 1978a: 451-456

TĚŚ́K, I.: Comparative morphological study on the tracheal epithelium of reptiles. Proc. XIXth Morphol. Congr. Praha, 1978b: 457-462

TĚ̉fK, I.: Ultrasturktur der Sekretzellen im Epithel der oberen Luftwege von Amphibien und Reptilien. Verh. Ant. Ges., 75, 1981: 383-384

TĚSÍK, I.: Ultrastructural morphology of the tracheal epithelium of some species of testudinates. Folia Morphol. (Prague), 4, 1982: 412-414 
TĚS̆K, I.: The ultrastructure of the tracheal epithelium in European common lizard (Lacerta agilis L.) and sand lizard (Lacerta vivipara Jacq.). Anat. Anz. Jena, 155, 1984a: 329-340

TÉŚIK, I.: Morphological study of the functional cycle of the secretory cells of the upper respiratory tract epithelium of amphibians and reptiles. Folia Morphol. (Prague), 4, 1984b: 391 to 394

TÉSfK, I.: Comparison of the morphology of upper respiratory tract epithelium in certain herpetofauna and avifauna representatives. Plzeñ. lék. sborn. Suppl. 51, 1986: 117-121

TRIER, J. S.: Studies on small intestinal crypt epithelium. J. Cell. Biol., 18, 1963: 590-620 
Plate XV.

Těšík I.: Differenees in the Mode ... pp. 11-15.
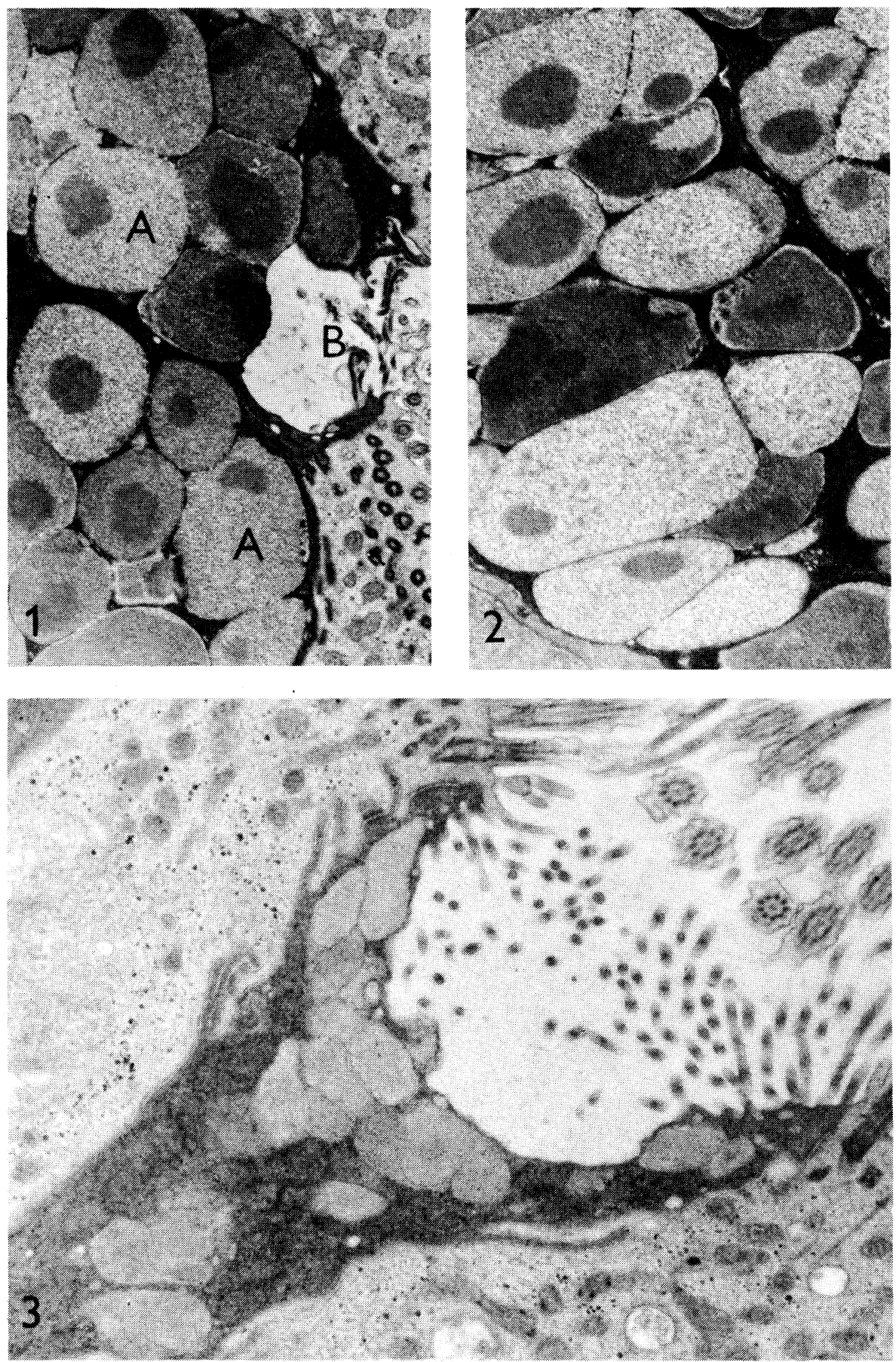
Plate XVI.
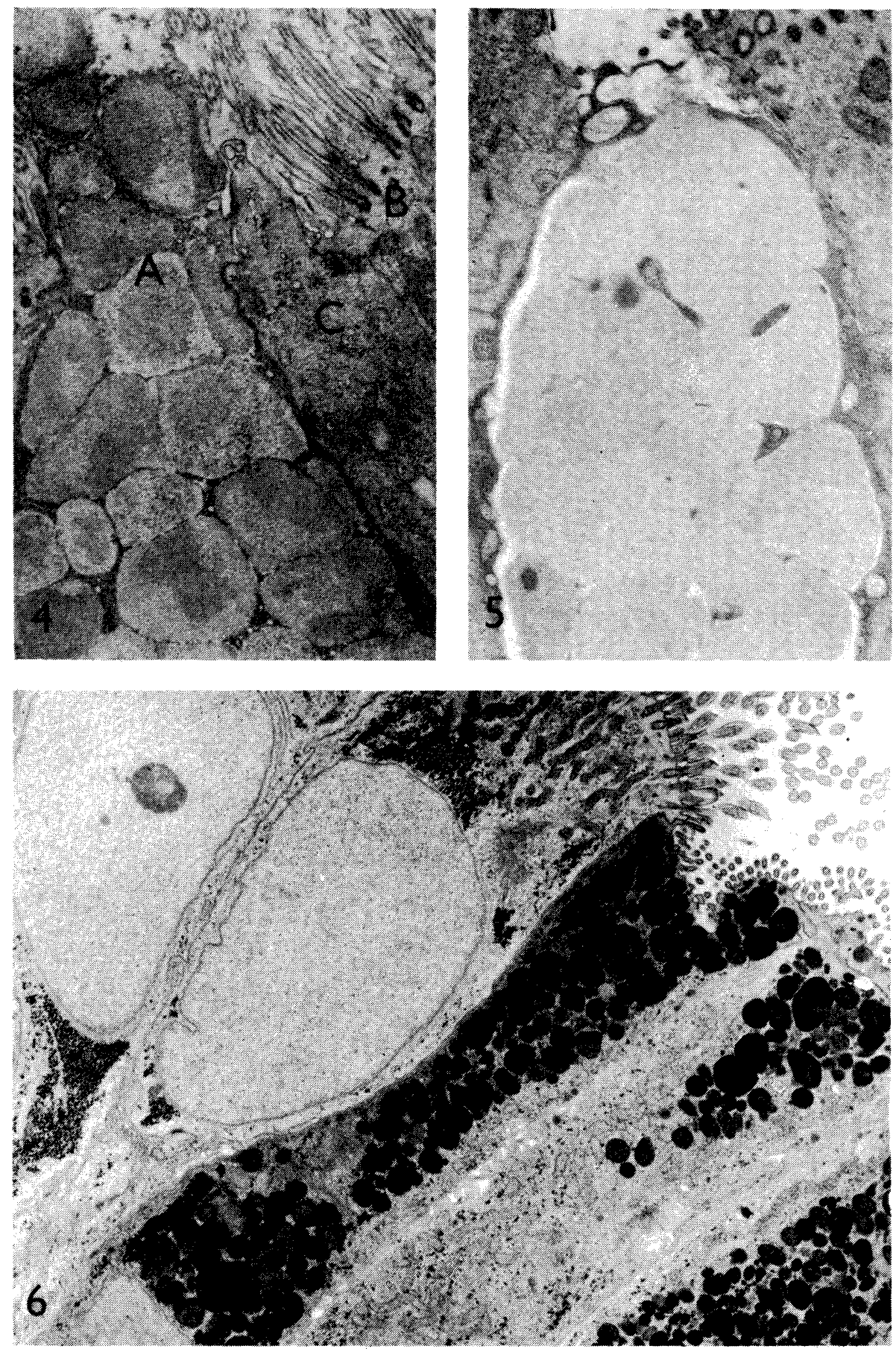
Plate XVII.
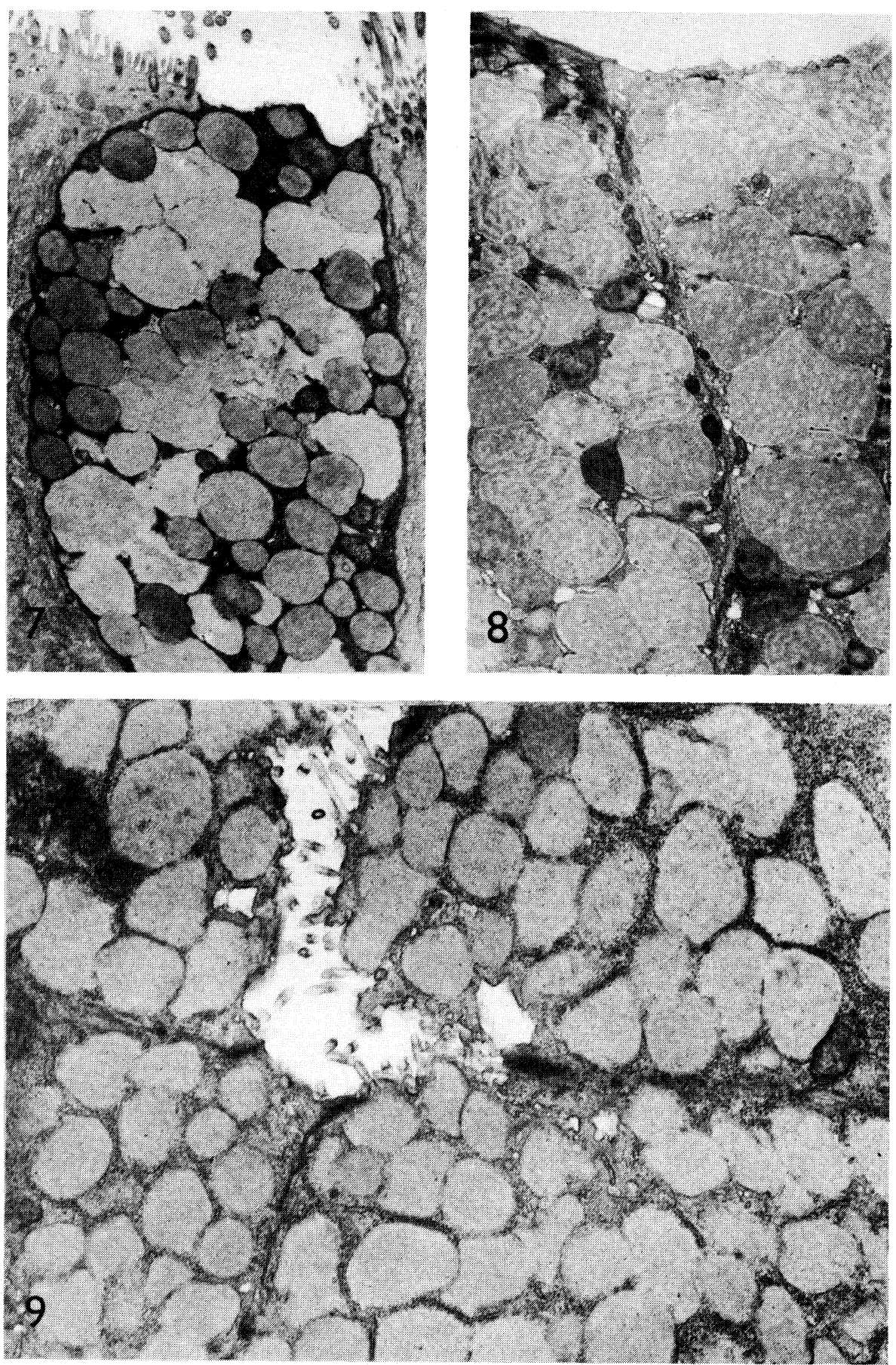
Plate XVIII.
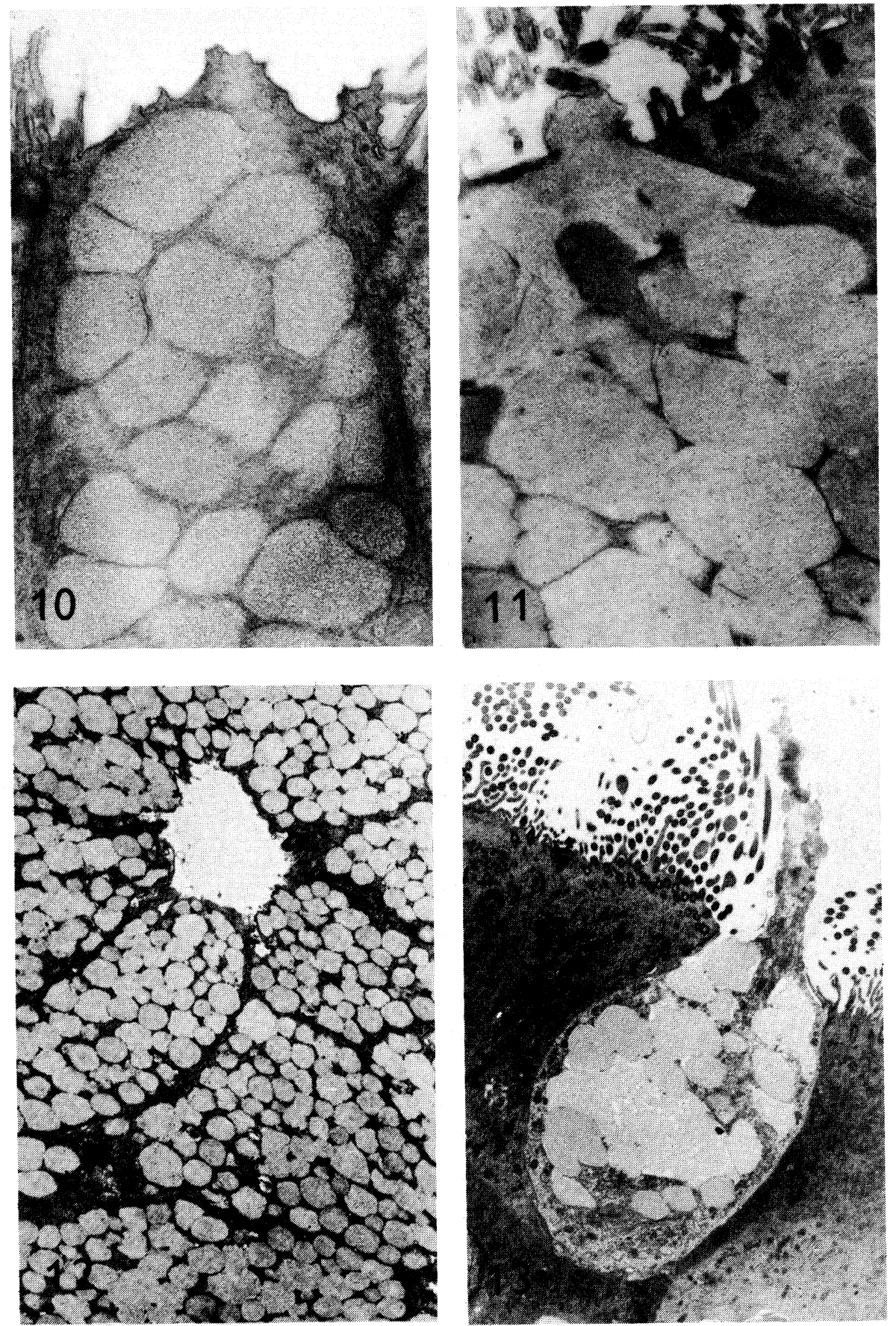
Těšík I.: Differencees in the Mode ... pp. 11-15.

Plate XV., Fig. 1. Anguis fragilis. Apical parts of two adjacent goblet cells surrounded by ciliated cells. A, secretory granules in various hydration stages; B, disturbed apical plasma membrane of the cell. $\times 7000$.

Fig. 2. Varanus grisseus. Details of secretory granules in various hydration stages accumulated in the cytoplasm of goblet cells of the endoepithelial gland. $\times 7000$.

Fig. 3. Anguis fragilis. An almost emptied goblet cell surrounded by ciliated cells. $\times 7000$.

Plate XVI., Fig. 4. Elaphe dione. A, secretiong goblet cell; B, ciliated cell; C, intermediary cell. $\times 7000$.

Fig. 5. Salamandra salamandra. A goblet cell with merging mucus granules and a impaired apical plasma membrane. $\times 7000$.

Fig. 6. Emys orbicularis. Goblet cells with solitary and only slightly hydrated mucin granules in the vicinity of ciliated cells. $\times 3000$.

Plate XVII., Fig. 7. Streptopelia decaocto. A goblet cell surrounded by ciliated cells. Note the various degrees of hydration and merging in the individual granules of its secretory product. $\times 3000$.

Fig. 8. Anser anser. Apical parts of two adjacent goblet cells filled with secretory granules hydrated in a mosaic-like pattern. $\times 4000$.

Fig. 9. Clethrionomys glareolus. Goblet cells of the tracheal gland with hydrated secretory granules. $\times 7000$.

Plate XVIII., Fig. 10. A goblet cell of the tracheal epithelium. Note the beginning of merging of the hydrated mucin granules. $\times 12000$.

Fig. 11. Lepus europaeus. A goblet cell at the start of secretion. $\times 7000$.

Fig. 12. Erinaceus europaeus. Mucin cells of the tracheal gland. $\times 2500$.

Fig. 13. Homo sapiens. A goblet cell in the initial phase of secretion. $\times 3000$. 